\title{
Beyond "PTSD": How stories and artworks that "make strange" can serve as signposts on new maps toward the communalization of military trauma
}

\author{
LAUREN SPRING, PhD Candidate, Adult Education and Community Development, University \\ of Toronto ${ }^{\mathrm{a}}$ \\ lauren.spring@mail.utoronto.ca
}

\begin{abstract}
The psychiatric system, in large part due to its reliance on the Diagnostic and Statistical Manual (DSM), has a tendency to pathologize ordinary human reactions to difficult life events, and to individualize treatments for "mental illness." This article builds on existing literature that is critical of psychiatry and proposes that art and stories that 'make strange' and elude easy interpretation may serve as a powerful counterpoint or complement to the "standard way of doing things' when it comes to mental health care. Using military trauma as an example, this article highlights the inadequacies of Post Traumatic Stress Disorder (PTSD) as a diagnostic category; and, drawing from critical literature in the field and the author's own experiences working with groups of traumatized veterans, it illustrates how and why ancient mythology and modern art especially may serve as useful tools for those who are having problems with living. The 'disorienting dilemmas' and consciousness-raising discussions such works evoke have the potential to touch on vital, nuanced, and philosophical aspects of trauma and suffering that are too often overlooked by the psychiatric profession.
\end{abstract}

Keywords: military trauma; mental health; modern art; theatre; ancient mythology; transformative learning; museums; PTSD.

\footnotetext{
${ }^{a}$ Lauren Spring is a PhD Candidate in the Adult Education and Community Development program at the University of Toronto. She also works as an Education Officer at the Art Gallery of Ontario where she provides tours, workshops, and lectures about the gallery's permanent collection and special exhibitions for a wide variety of different adult groups. Lauren is co-founder and creative director of Extant Jesters, a theatre company that uses improvisation, storytelling, Augusto Boal's Theatre of the Oppressed Techniques, and feminist consciousness raising methods to entertain, provoke and inspire diverse participant groups. Lauren holds an MA in International Development, and a BFA in Theatre and Development and has also completed studies at renowned physical theatre conservatory L'ecole Jacques Le Coq in Paris, France. She studied clown with Philippe Gaulier, and is a graduate of the Second City improv theatre conservatory. Lauren frequently employs arts-based and feminist research methods in her academic work. For her MA thesis, Lauren conducted a 3 month long participatory study with refugee women at the Canadian Centre for Victims of Torture, using improv theatre workshops to explore the relationship between humour, the body, and resilience. Lauren's current doctoral research (for which she received a SSHRC doctoral fellowship) explores "moral injury" and other aspects of military trauma that are overlooked by psychiatry and the Diagnostic and Statistical Manual. Her feminist and phenomenological approach draws on participants' lived experiences as well as their reactions to artworks about war, and will result in an interactive performance ethnography. A primary objective of this research is to help communalize veteran suffering and increase public understanding of the nuanced — especially gendered and philosophical—aspects of military trauma that go beyond the medical model. Lauren also writes creative non-fiction and theatre plays.
} 


\section{Icarus and Risk-Taking}

There is a painting on display at the Art Gallery of Ontario, entitled Daedalus and Icarus. The work, completed by Flemish Baroque master Anthony Van Dyck in 1620, depicts the moment before the young Icarus takes flight. For those unfamiliar with the myth, Daedalus and Icarus, father and son, have been trapped in a labyrinth on the island of Crete. In order to escape, Daedalus crafts a pair of wings — assembled out of wax and feathers - for his son to wear. Before the two set off, Daedalus warns the young Icarus not to fly too low where the mist from the ocean's waves may splash up and weigh down his feathers, nor too high lest the heat of the sun melt the wax of his wings. Icarus, however, doesn't heed this advice and ends up soaring high beyond the clouds toward the sun's burning rays and, as a result, tumbles fast into the sea.

This story has served as inspiration for countless artists throughout the ages. In Landscape with the Fall of Icarus, a late $16^{\text {th }}$ century world landscape work initially attributed to Pieter Bruegel, the painting's main subject is a ploughman who seems oblivious to the fact that, just metres away, a young boy has fallen from the sky into the sea — all we see of Icarus are his legs splashing about. Peter Paul Rubens, another Flemish baroque master, depicted the story as well in a 1636 sketch he titles The Fall of Icarus. His version (later adapted and painted by his student, artist Jacob Peter Gowy) depicts the climax of Ovid's narrative. It shows Icarus upside down and in full light tumbling to his death; his father looks on from the shadows, confounded and helpless. Van Dyck's depiction of the myth, however, is unique for two reasons. Firstly, he has opted to capture a moment in time before the climax of the fall; his painting shows Daedalus, face worn, standing behind his young son, lecturing him. The latter's magnificent wings tower over them both. Daedalus' index finger points skyward, Icarus' toward the earth, as if 
foreshadowing the flight and fall ${ }^{1}$. Secondly, and most importantly for the purposes of this article, in Van Dyck's painting, the young Icarus looks directly at the viewer, involving us in the decision making process. Icarus has a sparkle in his eye; his facial expression is at once grave and mischievous. Perhaps, no matter the danger, he knows exactly where he's headed. Or perhaps not; perhaps he'll set out heeding his father's sage advice, only to have his youthful sense of invincibility and over-confidence ignited by the sun's rays once outside of the labyrinth. Van Dyck's Icarus, not unlike a narrator character in Brecht's epic theatre plays who breaks down thefourth wall and address the audience directly - a device used to distance the audience from the action unfolding and to encourage them to reflect on how the story before them may relate to their own lives. In doing so, he brings us along for the ride, implicates us in the drama, and it's rousing.

Standing in front of this painting recently with a group of 14 young people (all of whom had been diagnosed with mental illness ${ }^{2}$ ), we discussed what we saw and how we felt about this version of Icarus. One member of the group offered that it seemed Icarus was asking us "what he should do" or to "judge his choice," inviting us to consider whether we would have behaved differently had we been in his position. Knowing how the story ends, it is easy to moralize. But, like much of Greek mythology, which tends not to dictate tidy lessons but seeks instead to explore the chaotic and orderly tendencies of human nature, it's not that simple (Graf, 1993). Icarus' decision to fly too close to the sun is equal parts bold and foolhardy, and may be interpreted in multiple different ways.

\footnotetext{
${ }^{1}$ The Van Dyck painting being described can be found at the following link: https://www.ago.net/anthony-vandyck-daedalus-and-icarus

${ }^{2}$ The author of this paper is an employee in the Public Programming \& Learning department of the Art Gallery of Ontario. The tours described in this article were part of a pilot project for which the AGO received funding for educators to provide free tours for community members diagnosed with mental illness and addiction. For more information about this program and its funders please visit https://www.ago.net/access-to-art-group-visits.
} 
This paper explores these grey areas where standard (i.e. Judeo-Christian influenced) morality, and the notions of what is "right and wrong" or "normal and abnormal" it has engendered, fall short. It argues that stories and art works whose meanings elude easy interpretation may, in fact, represent the complex experiences of those struggling with trauma or "mental illness" more accurately then can any DSM diagnosis.

At one point in our conversation in front of the Van Dyck painting, I asked the group: "Have you ever disobeyed an authority figure? Or taken a risk you knew others would advise against?" Many group members shared examples of how and when they had done this. Their stories ranged from low-stakes breaking of rules set out by overprotective parents, to much more serious transgressions we all promised we'd not share outside the group. In some cases, participants felt the rule-breaking and risk-taking was "worth it." Other times, they admitted, things “didn’t turn out well” and they deeply regretted their decisions. Many group members stressed, however, that it's impossible to know in advance the consequences one's choices may have, and that maybe sometimes 'flying too close to the sun' makes for a much richer life.

Our discussion also led us to consider contemporary society's double-standard when it comes to risk-taking. On the one hand, it is often romanticized; there are countless articles encouraging corporate leaders to take risks, for example (Pierce, 2013; Schoenberger, 2016). In a recent piece for Forbes magazine, Warrell (2013) encourages "leaders" to assess themselves by asking "where do you wish you'd been a little braver, trusted in yourself more... been less cautious in the chances you took?" and urges them to stop "catastrophizing" possible worst case scenarios because, after all, "fortune favours the bold." Clearly, "risk-taking" has become a buzz-word in many circles and there is now a faction of society that is encouraged and rewarded for 'making brave choices' and 'thinking outside the box.' Others, however, (many of whom live 
in the margins of society), are discouraged from trusting themselves, told to be more - not less — cautious about the risks they take. The youth participating in the gallery tour had first-hand, lived experience trying to navigate this contradictory set of rules. One participant, a young woman in her early 20 s, relayed an example of how she felt she could relate to Icarus. She mentioned that a few months after a particularly difficult year (during which she left a university program that wasn't the right fit for her) she decided that she would go and visit a close friend on the west coast of Canada. She had felt quite good about the decision until she told her psychiatrist, who saw it as a warning sign and a symptom of her (pre-diagnosed) mental illness. She pointed out that on this and other occasions, she walked out of her psychiatrist's office feeling very confused:

It can be easy to fall prey to misjudgement of doctors. Mine saw me as a patient whose life and decisions were controlled by my illness. ... Hearing this, and having my experiences presented to me as symptoms or unhealthy risk taking is unfair. I had come to trust my doctor so much, that I believed everything he told me and his interpretation of my story. ... For so long I took everything the doctors said to heart and it was their word against everyone, and I relied on their advice, and lived my life based on what they thought was best for me, it was challenging when I eventually realized ... that I didn't agree with the doctor and I felt that he was making some very big statements with not enough information. At first, I wasn't sure if it was me going into denial. If I was so "ill" that I was not capable of seeing the choices I made as unhealthy risk-taking. Anti- and critical psychiatry scholars have, for decades now, been calling our attention to the dangers, injustices, and pitfalls of the psychiatric profession and the DSM in particular (Burstow, 2015; Foucault, 1961/1988; Gailey, 2009; Laing, 1959/1965; Szasz, 1961). 
Burstow's piercing new critique, Psychiatry and the Business of Madness: An Ethical and Epistemological Accounting, does an especially good job of tracing the problematic history of the psychiatric system and outlining how and why even the most compassionate and wellintentioned health workers often end up operating in "bad faith" and providing patients with care that is unhelpful and sometimes even dangerous (Burstow, 2015, pg. 163-4). The fact alone that homosexuality and phenomena like hysteria ("a stereotypical woman's disease") used to be considered "disorders" in the DSM, proves that what psychiatrists describe as "symptoms" of "mental illnesses" are often little more than behaviours society deems unusual or that threaten the status quo (Burstow, 2015, p. 40). Laing (1959/65) has even argued that what the DSM labels as 'symptoms' might actually "best be seen as solutions to social and interpersonal dilemmas" (Burstow, 2015, p. 40).

The purpose of this article is two-fold. Focussing on the diagnostic category of PTSD, it serves first to critique the psychiatric system by bringing to light the many ways in which the DSM pathologizes ordinary (and often very useful) human reactions to difficult life events. It also proposes that the arts - especially when focussing on works that elude easy interpretation and inspire de-familiarization - may serve as a powerful counter-point or complement to the 'standard way of doing things' when it comes to mental health care. The following pages will highlight the inadequacies of PTSD as a diagnostic category; then, drawing from critical literature in the field and my own experience working with groups of traumatized veterans, I will illustrate how and why art and stories that "make strange" — a term I am borrowing from Kumangai and Wear (2014) — may be particularly useful tools for those who've received mental health diagnoses. Kumangai and Wear (2014) define 'making strange' as troubling “one's assumptions, perspectives and ways of being in order to view anew the self, others, and the 
world" (p. 973). My research explores how such provocations have the potential to touch on the vital, nuanced, and philosophical aspects of trauma too often overlooked by the DSM, and how arts-based approaches to trauma work may help communalize mental health care more generally Trauma and the trouble with "PTSD"

It is becoming increasingly clear that in many cases, 'normal' human reactions to difficult life circumstances or catastrophic events are being pathologized by the DSM and viewed as 'symptoms' of 'mental illness' (Burstow, 2015; Breggin, 1983; Hoge, 2010; Kirk \& Kutchins, 1992/1997). Nowhere is this more relevant and disconcerting than in the area of trauma. As a diagnostic category, PTSD is remarkably widespread. Today, it is applied to everyone from victims of rape to survivors of motor vehicle accidents, natural disasters, or residential schools; from refugees fleeing war-torn countries to soldiers returning from battle overseas. Indeed, this fact alone should serve as an indication that the diagnosis is relatively arbitrary and meaningless. Surely, if one groups a person with whiplash from a car accident into the same diagnostic category as a political prisoner who has suffered years of torture by her state, it is evident that profound philosophical aspects of these individuals' respective traumatic experiences are being ignored. The following pages will illustrate that this misrepresentation (formulated by the DSM and reinforced by the media and healthcare professionals) is dangerous; not only does entry into the psychiatric system often rob traumatized individuals of vital coping strategies they have developed, but it also frequently leads to "treatments" that have alarming physical, emotional, and inter-personal consequences (See Burstow, 2015; Healy, 2009; Spring, 2016; Schott \& Spring, 2016; Whitaker, 2002/2010).

The inclusion of PTSD in the DSM III (published in 1980) was largely a result of lobbying efforts on the part of Vietnam veterans in the USA who felt that they needed the 
American Psychiatric Association to construct a diagnosis so that their "long-term psychological damages could be recognized" (Burstow, 2005, p. 430). Such a recognition, it was thought, would also "pave the way for therapeutic services" they felt they needed (Burstow, 2005, p. 430), and it was initially seen as a positive step in terms of the state being forced to acknowledge the role they played in contributing to this trauma (as it was up to them to compensate veterans and help pay for treatment).

Up until this point, military trauma was viewed in a variety of different ways. During the First World War for example, soldiers displaying strange and unprecedented behavior were considered "shell shocked", and it was believed their conduct was a result of "concussions caused by the new high explosives used in battle" (Boone, 2011, p. 2). A diagnostic shift took place in 1943 when the US government, realizing they had spent more than a billion dollars on caring for psychiatric needs of WWI veterans, shifted the blame on to the victims and began to label their problems with living as "war neurosis", a condition thought to be caused by "inherent weakness or defective parenting and (only) aggravated by armed conflict” (Boone, 2011, p.2). The US government and military (now no longer responsible for having caused the trauma) considered themselves off the hook in terms of follow-up treatment and therapy and were quick to discharge any soldier "displaying psychiatric distress of any kind" (Boone, 2011, p. 2). As WWII went on, and as the United States found itself with an acute lack of manpower, the idea of "combat exhaustion" emerged and implied that military trauma was in fact not a "deep-seated pathology" that required immediate discharge from the military, but was merely circumstantial and could be treated with "rest, emotional support, and encouragement" over several weeks, after which soldiers could return rather quickly to battle (Boone, 2011, p. 2). The concept of "combat fatigue", however, had no real parallel in civilian psychiatry and was thus awkwardly 
incorporated into the category of "gross stress reaction" when the DSM was first published in 1952. In the second edition, published sixteen years later, the category of "gross stress reaction" was removed, thereby leaving psychiatrists without a clear model to better comprehend soldiers who had endured extreme stress and many military personnel without the 'professional' help they felt they needed (Boone, 2011).

Since the 1980s and the publication of the DSM IV in 1994 and DSM 5 in 2013, the diagnostic criteria related to PTSD have undergone several significant transitions. As a result of these shifts in language and criterion, a record number of people now receive the diagnosis each year. Diagnoses amongst military populations are particularly high: government statistics indicate that while between 2002-2014 'Depression' was the DSM diagnosis most commonly ascribed to Canadian military personnel (Pearson, Zamorski \& Janz, 2014), PTSD is now fast becoming the most common diagnosis amongst CAF members and veterans and now "accounts for the largest proportion of Operational Stress Injuries (OSI) encountered in the CAF" (Nazarov et al., 2015, p. 5). Nash and Litz (2013) have referred to PTSD as "one of the signature wounds" of the war in Afghanistan" (p. 365). In fact, $25 \%$ of those deployed to "combat heavy zones" in Afghanistan between 2001 and 2008 received a diagnosis of PTSD within four years of returning home (Nazarov et al., 2015, p. 5). Charles Hoge, a military doctor and US Army veteran himself, has also identified that "PTSD has gained a much higher level of importance during the wars in Iraq and Afghanistan than in any prior conflict” (2010, p. 1).

This increase in PTSD diagnoses amongst military populations, and the media attention such diagnoses and their related "de-stigmatization" campaigns have garnered might seem positive at first blush. Receiving a diagnosis does bring with it certain benefits: financial compensation from the state; or putting a name on complex emotions and behaviors, for 
example; for some who are suffering, the diagnosis may even lead to treatment they find helpful or life-saving. An increasing amount of critical research, however, indicates that much of what we think we know about military trauma is wrong ( Litz et al., 2009; Nazarov et al., 2015; Shay, 1994; Shay, 2014; Thompson, 2015). Not only does this lack of understanding about military trauma often result in dangerous courses of "treatment" for those who are suffering (Hoge, 2010), but it also diverts attention away from beneficial non-psychiatric and interdisciplinary approaches to helping service members and veterans - several of which are the focus of this article. While space constraints prohibit me from providing a full review of the negative effects that prescription drugs such as SSRIs are having on traumatized soldiers and veterans, these things have been widely reported elsewhere (Burstow, 2015; Hoge, 2010; Spring, 2016). Inappropriate and inadequate treatment approaches aside, there are many (even from within the field of psychiatry) who find fault philosophically with the way military trauma is being framed, diagnosed, and understood today.

For example, Hoge (2010) makes the point that many behaviors considered "symptoms" of PTSD by psychiatrists are actually the very "combat survival skills" that military personnel have been trained to exhibit. "Hyperarousal," considered one of four behavioral symptoms of PTSD in DSM-5, is a prime example, he argues (Hoge, 2010, p. 9). A state of hyperarousal and/or hypervigilance, Hoge reminds us, is unquestionably necessary in battle, and intensely encouraged during military training, hence, it's only normal that it should persist into civilian life. Neuroscientist Nancy Andreasen (1995) has also pointed out that, in many ways, the PTSD 'symptoms' military members and veterans exhibit are quite 'normal' considering the circumstances. After all, she argues, is it not 'normal' to have nightmares about being blown up by an IED in the desert, if that was a very real possibility in one's daily life for months or years? 
Is it not "normal" to be haunted by images of innocent civilians who were killed when caught up in your army's crossfire? She states: "PTSD is the only disorder that patients want to have: unlike all other psychiatric conditions, which imply defects of some kind, a diagnosis of PTSD confirms the patient's normality" (Andreasen, 1995).

Michael Balfour (2009), an Australian theatre director and university professor who has worked extensively with veteran populations in his home country, is equally critical of the diagnostic category and argues that it is in many ways ludicrous to group together individuals suffering from military-related trauma, with those living with non-combat related trauma (such as sexual assault victims, or survivors of natural disasters) as the DSM does. He says:

While PTSD sufferers in general are often victims of an event, military personnel may be perpetrators and victims. Many combat veterans develop PTSD as a result of traumas they have caused, such as killing people... Further, the ontological impact of engaging in legitimized acts of violence, authorized and sanctioned by the nation, places an individual in a complex moral and immoral, legitimate and illegitimate weave. (p. 8)

Balfour's final point is also echoed in the formidable critique brought forth by American psychiatrist Jonathan Shay. whose ideas, as I will outline below, have gained significant traction across North America in recent years.

For 20 years, Shay worked as the sole psychiatrist at the Veteran's Improvement Program, a clinic in Boston run by the U.S. Department of Veteran's Affairs. The clinic itself was established to "assist the most troubled and troubling" Vietnam veterans (Shay, 2014, p. 182). During his time there, working with countless veterans diagnosed with PTSD, Shay came to realize that this diagnostic category did not, in fact, accurately exemplify or validate his patients' experiences. For instance, the "Triggering Event" of PTSD (Criterion A in the DSM), is described as "actual or threatened death or serious injury" ("American,” 2010; Litz et al., 2009; 
Shay, 2014, p 185), but when Shay spent time with his patients, especially those suffering seemingly "lifelong psychological trauma" (Shay, 1994, p 20), he noted that no such event lay at the root of their trauma, but found there instead a profound sense of "betrayal of what's right by someone who holds legitimate authority in a high stakes situation" (Shay, 2014, p. 183). Shay began referring to this type of suffering not as PTSD but as "moral injury." Many other psychiatrists in the field, also disillusioned by the inappropriateness and ineffectiveness of PTSD diagnoses and treatments, took note and have embraced the idea that underpinning military trauma are not only "fear-based symptoms," (for several years Criterion A2 in the DSM stipulated that the "predominant painful emotions related to PTSD are fear, horror, and/or helplessness") but rather powerful feelings of guilt, shame, betrayal, and anger (Shay, 2014, p.

\section{"Moral Injury": Possibilities and Potential Pitfalls}

In recent years, several scholars and clinicians who work with veterans, have embraced Shay's idea of "moral injury." Most significantly, Litz et. al (2009) have "expanded the conceptualization of moral injury beyond the strict notion of betrayal by a commander or someone else in power" (Thompson, 2015, p. 5). Their definition also addresses that the psychological conflict related to moral injury may also result "from perpetrating, failing to intervene in, or witnessing acts that betray an individual's core beliefs" that is to say, that they have altered Shay's definition slightly to encompass the fact that not only a superior, but the soldiers themselves may have violated 'what's right' (Thompson, 2015, p. 6). They, like Balfour above, propose that in addition to being "victims or witnesses" of traumatic events (as outlined in the DSM), those living with moral injury may also have been "perpetrators" of these events (Shay, 2014, p. 185). Litz et al. (2009) also make the point that before PTSD appeared in the 
DSM III in 1980, many clinicians working with veterans actually did "tackle moral conflict and guilt" but DSM criteria have since steered professionals away from this line of thinking and responding (p. 696). Other clinicians, they argue, have always felt, and continue to feel that "addressing ethical conflicts and moral violations" is "outside of their realm of expertise" (p. 696). It is precisely for these reasons that I am proposing that certain aspects of military trauma can be better explored outside the realm of psychiatry entirely.

Energized by Shay's work, (and eager to embrace the concept of moral injury as a possible explanation for why so many PTSD treatments have failed over the years), many psychiatrists have already began attempting to adapt heretofore ineffective PTSD treatment approaches so that they may also address themes of betrayal, guilt and shame. (No doubt, in the DSM 6, "moral injury disorder" may well appear as its own diagnostic category). Well intentioned as their actions may be, by doing rushing to attempt to resolve moral injury with psychiatric solutions, these clinicians and researchers have overlooked two vital components of Shay's argument: (1) that we need a new paradigm in order to understand military trauma - old approaches to understanding simply won't do; and (2) "recovery" is only possible if we break with the one-on-one psychiatric model, and find a way to "communalize" trauma. The next section of this article will explore these elements in detail.

\section{Greek Tragedy and the Communalization of Trauma}

What makes Shay's work particularly remarkable is the unique way through which he came to articulate the disjuncture between his patients' suffering and the diagnostic category of PTSD and to coin the term 'moral injury' in the first place. As mentioned, he had long felt that PTSD as a diagnosis was "badly out of focus, badly missing what actually wrecks the lives of service members and combat veterans" $(2009$, p. 290) but while desperately seeking to better 
understand his patients and to find a means of representing the complexity of their experiences, Shay didn't delve deeper into psychiatry textbooks, but turned instead to Greek mythology Homer's Iliad, to be precise. Though written more than 27 centuries ago, Shay recognized in the epic "bitter experiences that actually do arise in war... things that we in psychiatry and psychology have more or less missed" (Shay, 1994, p. xiii). Through exploring the trials of Achilles, Agamemnon, Ajax, Odysseus, and others and by unpacking the complex relationships between these figures, Shay was better able to grasp how and why war, military service, and a "betrayal of what's right" can actually "ruin good character" and bring about the onset of what he terms the "berserk state" (xiii).

In his first book, Achilles in Vietnam: Combat Trauma and the Undoing of Character, Shay (1994) focuses on the tragedy of Achilles and argues that he "loses his humanity" in two distinct stages (p. 2). First, betrayal by his commander Agamemnon ${ }^{3}$ causes Achilles originally one of the most team-oriented warriors - to desert his own army and to lose affection for all but one of his "brothers in arms." While the Iliad shows us that Achilles initially cared deeply for his entire troop (the Myrmidons), after this betrayal by Agamemnon, “Achilles' horizon shrinks... to just one man, his foster brother, Patroklos" (28). As the story progresses, Patroklos sees that the Greek army is in danger. Understanding why Achilles refuses to fight under Agamemnon, Patroklos hatches a plan: he himself dons the armor of Achilles in order to threaten the Trojan army into retreating. At first, the plan is successful, but in time Patroklos (forgetting Achilles' warnings not to get carried away) becomes engaged in battle and is killed

\footnotetext{
3 According to Homer, at the start of the Trojan war Agamemnon upsets the god Apollo when he refuses to return a woman that he (Agamemnon) has taken as a battle-bride. This woman happens to be the daughter of one of Apollo's priests. Achilles plays a part in convincing Agamemnon that he must return this woman to her father or else the Greeks will suffer another plague. Agamemnon agrees, but then demands that Achilles give up his battle bride (a woman named Briseis who Achilles claims to love) to replace the woman Agamemnon has lost.
} 
by Hector - one of the strongest fighters in the Trojan army. After Patroklos death, Achilles feels his life is broken "into unhealable halves, with everything before his death radically severed from everything after" (Shay, 1994, p. 39).

Shay recognizes the powerful friendship between Achilles and Patroklos as being almost identical to that between countless veterans he has encountered who have lost a "special comrade" in battle or to suicide (Shay, 1994, p. 39). Using Achilles as an archetype to unpack how and why intense grief often transforms into rage after the loss of a close friend, Shay offers a compelling — almost feminist — analysis. Shay suggests that when trying to understand the relationship between Achilles and Patroklos, English language often fails. In Greek, Achilles refers to Patroklos as his "philos". Translators of the epic have difficulty deciding whether to translate "philos" (and "philia") as "friendship" or "love." When the term "friendship" has been used, the importance of their relationship is often undermined, but when replaced by "love," readers have been misled into believing that Achilles and Patroklos were not only foster brothers and close comrades, but actual lovers. Shay attempts to correct this, and is worth quoting at length on this point. He says that the term

philia includes many relationships that would not be classified as friendships. The love of mother and child is a paradigmatic case of philia; all close family relations, including the relation of husband and wife, are so characterized... philia includes the very strongest affective relationships that human beings form... (its) emphasis (is) less on intensely passionate longing than on benefit, sharing, and mutuality... Achilles' grief for Patroklos would not have been greater had they been a sexual couple, nor less if they had not been. (Shay, 1994, p. 41-42)

Shay goes on to say: "Many combat veterans are denied compassionate understanding by civilians, because so many people cannot comprehend a love between men that is rich and passionate but not necessarily sexual" (43). While in North American society today, compassion and nurturance are often viewed as being maternal qualities, “ancient Greek culture understood 
philia to be equally available to both genders" (49). Therefore, when a soldier loses a close friend in battle, they are left lamenting not only the loss of this comrade, but of a unique tenderness in themselves as well:

The terror and privation of combat bonds men in a passion of care that the word brother only partly captures. Men become mothers to one another in combat. The grief and rage that they experience when the special comrade is killed appear virtually identical to that of a child suddenly orphaned, and they feel that the mother within them has died with the friend. (49)

Shay continues this line of thinking through the rest of this book. He quotes veterans at length and relates their suffering and experiences to aspects of Homer's epic, offering that those exhibiting certain post-trauma behaviors pathologized by the psychiatric profession and the DSM today are actually in good company. His work provides a fine example of how stories may capture the complexities of trauma in ways that a list of diagnostic criterion does not.

Shay later went on to publish Odysseus in America: Combat Trauma and the Trials of Homecoming in 2003 which focused primarily on preventative psychiatry measures. In this book, and in countless speeches he has given on the topic since its publication, Shay insists that "community" is at the heart of any effective approach to helping those living with military trauma. In Shay's work with Vietnam veterans (and veterans from America's recent wars in Afghanistan and Iraq) he says:

...there are traditions built into the structure of American medicine, of American psychiatry...that elevate the one-on-one dyadic relationship between a skilled, empathetic, and engaged clinician and a single person in pain or trouble... Our belief is that recovery happens only in community... it means building a stable culture among the veterans that support their safety, sobriety, and self-care. (Shay, 2009, p. 288-289)

Shay insists that military trauma is not merely psychological but also "physiological...social... (and) cultural" (2009, p. 294). "Betrayal of what's right" for example "is in the realm of culture" 
(2009, p. 294). It follows, then, that approaches to helping those living with military trauma/moral injury ought to be truly interdisciplinary; aspects of them are cultural in nature. Shay argues that it's no coincidence that Athenian playwrights (Sophocles, Aeschylus) had military backgrounds and suggests that ancient Greek theatre (performed mostly for and by other soldiers as it was a time of constant warfare, and military service was mandatory) served a particular purpose: to make public the "paradoxical logic of war" and to restore themis — what is "right" (Shay, 1994, p. 230). Theatre was the community's way of receiving and reintegrating soldiers into the "social sphere as citizen" (230). He says: "Any blow in life will have longerlasting and more serious consequences if there is no opportunity to communalize it. This means some mix of formal social ceremony and informal telling of the story with feeling to socially connected others who do not let survivors go through it alone" (Shay, 1994, p. 39).

Classicist and theatre director Bryan Doerries has, for several years now, been putting these ideas into practice with tremendous effect. In Theatre of War: What Ancient Greek Tragedies can Teach us Today, Doerries credits Shay with inspiring him to direct staged readings of plays by ancient Greek tragedians for military populations. Having now performed at army bases, veteran treatment facilities, and military conferences across the United States, Doerries has found that staged readings of scenes that reflect feelings of guilt, shame, and a "betrayal of what's right" (emotions at the heart of moral injury) for audiences of service members, veterans, and their families are indeed a powerful way to communalize trauma and to introduce the complexities of moral injury while moving past the "sterile, scientific-sounding acronym" of PTSD (Doerries, 2015, p.102). Doerries discusses in detail why Sophocles' story of 
$\operatorname{Ajax}^{4}$ (whose name literally translates to mean "scream"), which not only recounts a profound military betrayal but also puts the suicide of a combat veteran at the heart of the drama, has proven to be particularly provocative for audience members. He writes at length about how Ajax's speech just prior to killing himself in front of his war-bride Tecmessa has been particularly cathartic for spouses of veterans, for example. Many military wives, like Tecmessa, regularly awake in the middle of the night being strangled by their husbands in the throes of a nightmare. Doerries also reminds us that "Tecmessa is a minor character in Greek mythology... Yet Sophocles purposefully placed her at the centre of his play, gave her a comparable number of lines to his central character, bestowed her with Ajax's young son, and assigned her with some of the most moving speeches in the entire play" (Doerries, 2015, p. 131). Wives of military personnel today relate easily to her attempts to "jar [Ajax] loose from the insidious logic of his suicidal thoughts" (Doerries, 2015, p. 123).

Doerries reminds us that in Athens in fifth century BCE all men in society were members of the military, and that generals and lower ranking members of the army would regularly gather together to watch these plays. He thrills now at creating a similar environment at conferences and treatment facilities. He says:

[Ajax's death] is one of the most graphic and iconic depictions of suicide in all of Western literature. Sophocles staged the violence of Ajax's death mere feet from where the generals' sat in the audience... [and] took the audience inside the mind of a person contemplating suicide... (96).

\footnotetext{
${ }^{4}$ In Sophocles' play, after Odysseus dishonorably wins the armor of Achilles (that rightfully should have been awarded to Ajax), the latter begins to exhibit indignant rage and vows to take revenge on the Greek leaders who betrayed him. But Athena tricks Ajax into slaughtering a group of sheep and cows instead. As the epic unfolds, Ajax becomes tormented by shame, profound grief, and suicidal longing which transform into a "berserk state" that eventually leads him to impale himself with his own sword in spite of the frantic pleadings of his war bride, Tecmessa, who begs him not to take his own life.
} 
Doerries recounts a particularly memorable moment after a staged reading of the play where the highest ranking mental health professional from the US Army, General Sutton, came up to him, visibly shaken to have witnessed up close the role that betrayal by superiors played in Ajax's turmoil. Approaching Doerries after the performance, she offered: "Perhaps... Sophocles wrote these plays to comfort the afflicted and to afflict the comfortable" (108).

This idea, it seems, is key. Military personnel, veterans, and their family members took comfort in relating to these characters more than 2000 years ago in Athens, and they still do today. However, the other key purpose of these plays is to complicate the story, to move attention away from the behaviour and suffering of any individual soldier, and raise broader questions about morality, accountability and injustice that contribute to said behaviours and suffering.

Tragedies are designed not to teach us morals but rather to validate our moral distress at living in a universe in which many of our actions and choices are influenced by external powers far beyond our comprehension - such as luck, fate, chance, governments, families, politics, and genetics. (Doerries, 2015, p.13).

As illustrated earlier, Van Dyck's painting of Icarus, which shows the moment before the tragedy occurs and implicates the viewer in the protagonist's decision making process, certainly induced critical reflection about issues related to trust, authority, and risk-taking amongst the youth who stood before it debating whether or not he (and they) were/are right to "fly too close to the sun." Doerries' staged readings, which present big moral questions about war and betrayal, have a similar objective. They not only provoke strong visceral reactions amongst those in attendance, but also complicate the conversation about military trauma beyond DSM definitions of PTSD. That is to say, these presentations "make strange" the formerly familiar so that audience members — doctors, wives, military commanders - may see it through new eyes. 
It is interesting to note that Doerries was initially wary of presenting these staged readings for military populations for fear that (a) they might re-traumatize audience members, and (b) the classic texts would be too difficult to understand. Neither of these things proved to be a problem, however. It turns out that one doesn't need a $\mathrm{PhD}$ in classical studies in order to connect to ancient characters and their turmoil. Also, while many audience members were visibly moved and troubled by the stories of Ajax and other soldiers, the decision to produce these plays as staged readings as opposed to full productions (with dramatic lighting and sound effects etc.) allowed audience members to maintain a certain distance from the action. This distance ensured that audience members could simultaneously be swept up in the emotion of the story while also reflecting rationally about characters' actions and choices. Doerries also feels it is important to follow up these staged reading performances with talk-back sessions where members of the audience (along with veterans and their families who travel with his theatre company and help facilitate these dialogues) share stories about how they relate to the characters in the play.

The next section of this article suggests that visual art, especially modern works whose meanings are obscured and hence allow for multiple interpretations, may serve a similar purpose. Drawing from my own experiences facilitating an art gallery tour with a group of Canadian Armed Forces veterans diagnosed with PTSD, I will illustrate how modern art works can help induce 'disorienting dilemmas' and spark complicated conversations that communalize trauma in ways similar to those outlined above.

\section{Modern Art and "Making Strange"}

Kumangai and Wear (2014) have been using modern art as a learning tool in medical education for quite some time now and argue that one of its crucial benefits is "to 'make strange' 
(p. 973). They point out that just as modern theatre (especially Bertholt Brecht's conception of it) is designed to "question and challenge existing power relationships," so too can modern art make the familiar fade away and "disrupt automatic recognition [through]... cognitive disequilibrium" (p. 973-4). They provide numerous examples of how looking at and talking about modern art can induce or touch upon key realizations, or what transformative learning theorists call "disorienting dilemmas." Disorienting dilemmas are considered by transformative learning practitioners to be the vital first step in a consciousness-raising process through which one's prior frame of reference or perspective on the world is altered. Kokkos (2010) and other transformative learning practitioners such as Dirx (2006/2012) and Taylor (2008) have argued that there are both rational and 'extra-rational' components to transformative learning, and that adult educators must not ignore the fact that symbols, metaphors, and emotions that serve as a "gateway to the unconscious" are equally as vital to what Freire would term "conscientization" as are rational discussions and analyses (Kokkos, 2010, p. 165). Kokkos (2010), who has done a vast amount of research into the relationship between aesthetic experience and transformative learning, has come to the conclusion that artworks that are abstract or non-representational in nature are uniquely useful as they, like Doerries' staged readings, provide participants with the opportunity to "combine critical reflection with the affective and imaginative dimensions of learning" (Kokkos, 2010, p. 166). Kumangai and Wear echo this statement when they point out: "modern art is particularly noteworthy... and in fact, one might argue that the whole of modern (and especially postmodern) aesthetics is designed to disrupt and subvert assumptions about art, human beings, nature, and life" (p. 975).

To illustrate how this process might unfold in practice, and how disorienting dilemmas may be induced and unpacked by facilitators and participants in a group setting, I will cite an 
example of a recent conversation that transpired with a group of Canadian Armed Forces military personnel who were all seeking treatment for PTSD. The group of nine came to the Art Gallery of Ontario ${ }^{5}$ for a 75 minute guided tour to look at artwork that related to war in some way. Though space constraints here limit me from recounting the entire experience, I will focus on a moment during the tour where participants' strong visceral reactions to a work of art prompted a particularly 'charged' discussion that helped bring a variety of 'disorienting dilemmas' to the surface.

Approximately 45 minutes into the tour, I led the group to a sculpture titled Warrior With Shield 6 by modern British sculptor Henry Moore. Moore himself had fought in WWI, and served as an official war artist during the Second World War. Countless art historians have argued that Moore's sculptures and drawings from the 1920s onwards were hugely impacted by his own military trauma, so the piece seemed an appropriate choice for this group. Warrior With Shield is a representational, though non-realistic, depiction of a war-injured figure - it is missing several limbs. As soon as our group approached this work, one participant ${ }^{7}$ who had been relatively quiet and withdrawn throughout the tour up until this point reacted immediately to the piece. Our conversation went like this:

BRAD: He's a coward.

LAUREN (me): What do you mean?

BRAD: He let himself get his leg blown off. He's a coward, he's weak. That's his own fault. He deserves to die. He should die... He's just getting what he deserves.

LAUREN: What makes you say that? Why is he a coward?

BRAD: (Walking around the sculpture) He's missing his fucking leg! And his fucking arm. He's missing half his fucking body! He's not going to make it. And he's leaning

\footnotetext{
${ }^{5}$ The Art Gallery of Ontario approved this research, and participants consented to take part in it.

${ }^{6} \mathrm{~A}$ link to an image of the sculpture can be found at: https://www.ago.net/agoid8806

${ }^{7}$ All participants' names have been changed.
} 
back, away from the danger. Look, he's leaning back — like a coward. What a stupid fucking coward.

The entire group (myself included) was somewhat taken aback by Brad's strong reaction again, he had said very little up until this point in the tour. It was clear that this figure offened him in some way. After a brief pause, I asked:

LAUREN: Does anyone see it differently? Does anyone feel this figure is not a coward? Roy responded slowly:

ROY: He looks brave to me. I know he is injured and hesitating to fight, but he's still in the battle and that counts for something. Like he's leaning back, yah... But he's... still moving forward even though he's really hurt. He even has his shield up, so he still cares about his life. He still wants to try to protect himself even though he's weakened. He hasn't given up.

I encouraged the group to walk around the sculpture and to look at the subtle choices Moore had made and to consider what these choices might represent. One participant offered a particularly profound observation:

CHRIS: Maybe it's not a real shield. I see this guy differently. I don't think he's in a war zone. I think he's back home and I think it's an emotional shield. Like he's not actually holding anything, the shield just represents how he's cutting himself off from everyone. He is hurt and suffering, but closed off.

Another group member then chimed in:

SAM: I think Chris is right. I think this guy just got home after being deployed because he's all alone. When you're at war, you're never alone like that. Like literally never alone.... Someone's always got your back... But the artist showed this guy being totally alone. He could have sculpted other people in there but he didn't.

LAUREN: Do you think this figure is actually alone? Or just feels that he's alone?

JAY: Could be either way. You told us that Henry Moore lost most of his buddies in his regiment in WWI, so maybe it's literal, that he's feeling that loss. 
RASHID: Or maybe there are actual people around him, trying to help or whatever, but what they are doing makes it worse and so he'd rather be alone.

Our conversation progressed from there. As facilitator/ tour guide, I continued to probe as to why/ how a soldier returning from battle could feel alone while actually surrounded by wellintentioned people. Several participants seemed eager to explain to me their frustrations about the medical system, saying they have "friends who are hurting, and no one is helping them... They put their lives on the line for the country and then they are just abandoned ... treated like dirt." Others voiced concern about how quickly their doctors offered them medication, how they felt they didn't have a choice but to accept to take it, all the while they were wary of the side effects. One participant recalled how some of his veteran friends who were given drugs "can't even fuck their wives" (presumably a reference to the erectile dysfunction caused by some PTSD drugs) "or think properly anymore."

As the discussion went on, participants also got into a debate about why Henry Moore would have made this figure's face so strange and "pinched looking." Brad said he felt that it was because this "coward" soldier had a "stupid puny fish head" that represented his weakness, while others in the group said it was because this warrior figure was "focused" or in "survival mode... just trying to look straight ahead and stay alive."

There were several times during the discussion that participants turned to me and asked: "what is it supposed to mean?" And each time I reminded them that the artist left the meaning ambiguous for a reason because he wanted viewers like them to project their own meanings on to the figure. I also stressed that having been in war zones themselves, they were in many ways better positioned to understand this sculpture than I was; they could bring an entirely different perspective than I could. We also discussed how, in life, we rarely feel just one thing at a time. 
We might feel both brave and cowardly in the same moment; this is perhaps why it can be unsettling to observe this sculpture. Though we seek answers from it, the more time we spend examining its angles and textures, Moore's figure only raises more questions.

This short excerpt from our conversation cited above reveals several things: (a) Looking at art can help participants address and articulate pre-existing frames of reference or 'disorienting dilemmas' and gives them an external object upon which they can project their feelings/ fears/ worries, without necessarily having to acknowledge them directly (i.e. Brad's comments regarding cowardice/perceived weakness were about the sculpture and not himself, but still allowed for those around him to better understand his current frame of reference). Through questioning and probing deeper into the ideas and stories offered up by participants, the facilitator can use modern art pieces to induce disorienting dilemmas. For example, the fact that Moore's sculpture was non-realistic likely helped Chris and Sam feel they had permission to view its story abstractly: to imagine the figure was not on the battlefield at all, but holding up a symbolic "emotional shield" upon return to civilian life. (b) Looking at a modern sculpture can provoke strong visceral “extra-rational” reactions — even amongst those who don't have a detailed knowledge of art history. This point is key: just as Doerries feared that it might be difficult for military populations to connect with ancient Greek tragedies because the plays have a reputation for being 'difficult to understand' for those who have not studied the classics, I have often heard people assume that modern art will be 'over the heads' of those who don't frequent galleries on a regular basis. However, Brad's near gravitational pull towards Warrior With Shield, and the nuanced group discussion that followed as we considered all aspects of Moore's figure, should serve as a powerful demonstration that 'non-experts' are, in fact, fully capable of forming powerful, insightful opinions about artworks and making meaningful connections 
between what they see and their own lived experiences. (c) The communalization of trauma is vital; a non-clinical group setting allows for a sort of consciousness-raising that is simply not possible in a one-on-one session with a "professional" or even within group therapy sessions. Standing beside Warrior With Shield, participants were able to build on one another's points of view to inform their own perspectives. For example, when Brad insisted that this warrior figure was a coward, Roy felt inclined to read things differently in response, which opened up the possibility for Brad to re-consider his way of seeing things (or at least to recognize that his way of interpreting the world is just one amongst many). When Chris suggested that perhaps this figure wasn't fighting in a literal battle, but was instead struggling upon returning home, it encouraged other members of the group to move the discussion away from judging the individual figure's cowardice or bravery towards critiquing outside supports that are supposed to be in place to help veterans transition into civilian life. It was even suggested that perhaps this figure had sought help, but was further injured as a result and so was now isolating himself as protection from an untrustworthy system and society.

Just as many transformative learning theorists have drawn on the work of Carl Jung to illustrate the importance of symbolism, the unconscious, and the "extra-rational" aspects of learning, Baydala and Smythe (2012) have used Jung's theory of archetypes and his ideas surrounding the collective unconscious to inspire a practice that they term "critical presentism". The ideas they present also help illustrate why and how specific ways of looking at modern art and/or reading ancient literature can serve as a counterpoint to psychiatric approaches to understanding human experience as it relates to mental health. They argue that, if explored symbolically, ancient stories "can be a source of fresh articulation for a current problem" (p. 854). The authors caution, however, against what they term "naive presentism" (p. 842, a 
tendency amongst medical professionals to diagnose ancient artists, writers, or fictional characters appearing in their works using present-day DSM criteria. "Naïve presentism," they maintain, “essentializ(es) another world in order to reinforce one's own understandings" (p. 842) and thereby "distorts the unique meanings of the time in which the literature was produced" (p. 843). Employing a hermeneutic reading of Jung's theory of archetypes, they encourage those drawn to ancient literature and art to practice "critical presentism" instead and to focus on the symbolic dimension of works in order that they may help access "continuity of human meaning without reifying understanding into explanation" (846). It is my belief that the group discussions that ensued around the Van Dyck painting and the Henry Moore sculpture serve as examples of "critical presentism" in practice. Rather than pathologize the subjects in these works conceptually (by assuming Moore's warrior had PTSD, or Van Dyck's Icarus was experiencing a manic episode), I provided basic details about the lives of the artists, and the time periods they were living in before the group began considering the symbolic aspects presented and imagining a multitude of possible narratives based on their own worldviews and experiences. Baydala and Smythe state that with respect to ancient literature, critical presentism can "open a wide range of possible readings [rather than] sell a particular interpretation... [that is] entirely appropriated by the present. The archetypal thus remains opaque and continuously available for alternative readings." (p. 852) My belief is that modern artworks, whose meanings are often opaque and open to interpretation to begin with (i.e. The Warrior's head could be considered "puny" or "focused" depending on the viewer's frame of reference) must also be met in this way. As Shay (1994) has argued, the communalization of trauma has its foundation in the fifth century BCE. However, its critical consciousness-raising aspects also owe much to the feminist movements and CR groups of the 1960s and 70s whose participants were adamant that what they were doing 
was distinct from group therapy. Whereas "therapy" tended to focus on how an individual had failed to adapt to "normal" social conditions, consciousness-raising groups (wherein women would share stories and personal experiences) helped participants to uncover and explore the ways in which these conditions as well as larger, patriarchal social structures continued to oppress them (Gardner et al., 1971).

Shay's decades of experience working with veterans has led him to proclaim that for veterans with profound psychological injuries "a stable, trustworthy, and safe community of other veterans" is "the royal road to recovery" (2009, p. 289). For those who feel they have been betrayed by their superiors in the army, or are haunted by their own actions or inactions while on the battlefield, this sense of community is vital. Shay says: "What is left when social trust is destroyed is not a vacuum, not nothing, but the active and potentially quite dangerous expectancy of harm, exploitation and humiliation from every person or institution that they encounter" (2009, p. 289). Doerries' staged readings of Greek tragedies and the follow-up discussion that ensue have gone a long way to help create community, re-build trust, and address the aspects of trauma that psychiatry ignores. I am proposing that guided art gallery visits may help traumatized military personnel come together in a similar way; not to "heal" per se, but to connect with one another so that they may feel less alone in their pain and with their feelings of injustice.

\section{Conclusion}

I have argued in this article that art-viewing and storytelling may serve as a powerful counterpoint or complement to the 'standard way of doing things' when it comes to mental health care (especially when focussing on works — such as Greek mythology or modern art — that elude easy interpretation). I have provided several examples from the literature and my own 
personal experience facilitating art gallery tours for people diagnosed with mental illness to illustrate how reviewing these stories and artworks through a "critical presentist" lens can both induce new and touch upon existing 'disorienting dilemmas'. PTSD's growth in popularity in recent years - in spite of evidence that its very existence as a diagnostic category is in many cases inappropriate - serves as a crucial example of the DSM's tendency to pathologize ordinary human behaviour and vital coping strategies. Jonathan Shay, astute to this paradox in his decades of work with veterans, came to argue that those with the most debilitating militaryrelated psychological trauma, were not suffering from PTSD at all, but from feelings of betrayal, shame, guilt — what he came to term "moral injury." His admonition of DSM-inspired approaches to treatment is relevant not only for those who work with military populations, but for all psychiatrists:

before analyzing, before classifying, before thinking, before trying to do anything-we should listen. Categories and classifications play a large role in the institutions of mental health care for veterans, in the education of mental health professionals, and as tentative guides to perception. All too often, however, our modes of listening deteriorate into intellectual sorting, with the professional grabbing the veterans' words from the air and sticking them in mental bins. To some degree that is institutionally and educationally necessary, but listening this way destroys trust (Shay, 1994, p. 4).

This breakdown of trust was very much in evidence amongst the youth at the gallery who stood in front of the painting of Icarus, and who, while debating the merits of risk-taking, shared that they felt let down and misunderstood by the psychiatrists put in charge of their care. What I have proposed in these pages, is that the sort of listening Shay calls for entails a new framework, one that consists not of diagnostic manuals or lists of symptoms with checkboxes, but of art and literature that "makes strange" and helps us understand the nuances and complexities associated with trauma and other problems with living. 
Bryan Doerries (2015) reminds us that the lives of all citizens living in Athens in the fifth century BCE were directly impacted by war. As a community, therefore, they developed a means through which to address, better understand, and cope with combat-related trauma: "Storytelling, philosophy, art, and war were vitally and inextricably interconnected" (p. 76). This is no longer the case in North America today. It is up to soldiers, veterans, and others who are struggling to navigate their way through these experiences on their own, or in quiet rooms with an "expert." It is up to them to attempt to find words to articulate their feelings and experiences to concerned family members and friends. But sometimes words fail us, or, once spoken aloud, only trivialize an experience. Sometimes, try as we might to draw a moral lesson or a tidy conclusion from a troubling event, we are left feeling only abandoned, disoriented. It is in these moments that aesthetic experience (in the form of staged readings, paintings or sculptures) proves most valuable and necessary.

The aesthetic experience... offers to participants the possibility to process a variety of symbols through which it is possible to articulate holistic and delicate meanings, to draw on emotional and imaginative situations, to use metaphors and in general to express different perspectives of reality-leading thus to the awareness of issues which may not be easily comprehended through rational argument. (Kokkos, 2010, p. 157)

Doerries echoes this idea when he says: "The Greeks knew that live drama had the power to convey the spirit of an ultimately indescribable experience” (2015, pg. 76).

There is evidence that arts-based community trauma work may bring with it ancillary benefits as well. For example, research conducted by Kokkos (2010); Potash et al. (2013); and Roberts et al. (2011) recognizes the fact that distinctly non-clinical settings (like public art galleries or theatres) help promote "social inclusion" for those who feel stigmatized because of the mental health problems that impact their lives. It seems indeed that such environments are a welcome change - a space where they may speak their mind without worrying that their words 
are part of an "assessment" where their perspectives and opinions can be twisted into symptoms. Many individuals who have come for tours at the Art Gallery of Ontario as part of the program developed for those diagnosed with mental illness or addiction have given similar feedback. Some participants I have worked with remarked that they were surprised to feel so accepted in the gallery. Some even reported feeling that their special status - having been invited for a free private tour, being met by an education staff member at the front door, given complimentary coat check — made them feel like "VIPs". Many participants have also reported that it was a relief to do something so stimulating alongside the general public, that it felt nice during tours to have a staff member really care about their opinions, and to have other gallery visitors listen in on the tour and their interpretations of the art works.

Shay (2009) and others recognize that:

there are traditions built into the structure of American medicine, of American psychiatry, but also into the traditions of clinical social work that elevate the one-on-one dyadic relationship between a skilled, empathic, and engaged clinician and a single person in pain or trouble.

It can be difficult to stray from such traditions, no doubt. But Shay also argues that we would all do well to take a lesson from the Greeks and find creative ways to conceptualize and “communalize" trauma work (p. 289).

Homer, Aeschylus, Euripides, and Sophocles, as well and Anthony Van Dyck and Henry Moore, along with countless other ancient, modern, and contemporary artists, offer us a new vocabulary for discussing problems with living.

The ability of the arts to 'make strange' does something else in addition to prompting critical inquiry and action. By forcing us to reconsider familiar ideas, situations, and relationships in new and different ways... it frees thought and reflection to pursue entirely new avenues of questioning and discovery. It stimulates us to fully appreciate the wonder and mystery that lie at the core of human interactions during times of struggle. (Kumangi \& Wear, 2014, p. 976) 
Van Dyck's Icarus is summoning us to not be afraid of such wonder and mystery; Homer and Sophocles have provided avenues through which we can delve deeper into these things. Moore's warrior, battle weary as he may be, has the capacity to remind us that we may all be both courageous and cowardly, resolute and apprehensive at the same time, and that our most compelling features are often difficult to define. In fact, sometimes words fail us all together. This is where art enters in: it can express the unspeakable. Guided art tours and play readings with follow-up discussions don't promise easy answers, nor a clear path from "illness" to "recovery," but by helping "communalize" what has for too long been a lonely expedition, these approaches restore trust, and move attention away from individual actions or inactions in favour of critiquing broader systems and structures. They also assure that those confronting problems with living will be in good company when the most difficult questions arise on the long and arduous journey ahead.

\section{References}

Allen, Pamela. (1970). The small group process. Radical Feminism 2000, 277.

American Psychiatric Association. (2010). Diagnostic and statistical manual of mental disorders ( $4^{\text {th }}$ ed., text rev.). Washington, DC: American Psychiatric Publishing. American Psychiatric Association. (2013). Diagnostic and statistical manual of mental disorders ( $5^{\text {th }}$ ed.). Arlington, VA: American Psychiatric Publishing.

Andreasen, N. C. (1995). Posttraumatic stress disorder: psychology, biology and the Manichean warfare between false dichotomies. American Journal of Psychiatry, $152,963-965$

Balfour, Michael (2009). The difficult return: Contexts and developments in drama-based work with returned military personnel. Applied Theatre Researcher, 10, 1-11. 
Balfour, Michael. (2012). The art of return: Aesthetic approaches to work with returned military personnel with trauma-related conditions. In C. Marin and P. Taylor (Eds.), Theatre and social change, Peter Lang.

Baydala, A., \& Smythe, W. E. (2012). Hermeneutics of continuity: Theorizing psychological understandings of ancient literature. Theory \& Psychology, 22, 842-859

Boone, Katherine N. (2011). The Paradox of PTSD. The Wilson Quarterly 35(4), 18-22.

Boserio, G. (2013). The untold cost of moral injuries in war. http://www.abc.net.au/radionational/programs/latenightlive/anzac-day/4648634. Retrieved March 6, 2016.

Breggin, P. Psychiatric drugs: Hazards to the brain. New York: Springer.

Brotsky, S. \& Giles, D. (2007). Inside the "pro-ana" community: A covert online participant observation. Eating Disorders, 15(2), 93-109.

Burstow, B. (2005). A critique of post traumatic stress disorder and the DSM. Journal of Humanistic Psychology, 45(4), 429-445.

Burstow, B. (2015). Psychiatry and the business of madness: An ethical and epistemological accounting. New York: Palgrave Macmillan.

Dirx, J. M. (2006). Engaging emotions in adult learning: A Jungian perspective on emotion and transformative learning. In E.W. Taylor (Ed.). Teaching for change. New directions for adult and continuing education, no. 109. San Francisco: Jossey-Bass.

Dirx, J. M. (2012). Nurturing Soulwork: A Jungian approach to transformative learning. In Taylor, E. W., \& Cranton, P. (Eds.). The handbook of transformative learning: Theory, research, and practice. San Fransisco: John Wiley \& sons. 
Doerries, B. (2015). The theatre of war. New York: Alfred A. Knopf.

Foucault, M. (1961/1988) Madness and civilization. New York: Random House.

Gailey, J. (2009). "Starving Is the Most Fun a Girl Can Have”: The Pro-Ana Subculture as Edgework. Critical Criminology, 17(2), 93-108.

Gardner, J. (1971). Consciousness-raising. Voices of Women's Liberation.

Graf, F. 1993. Greek mythology: An introduction. Baltimore: Johns Hopkins University Press.

Healy, D. (2009). Psychiatric drugs explained. London: Elsevier.

Healy, D. (2010). Pharmageddon. Berkeley: University of California Press.

Hoge, C. (2010). Once a warrior, always a warrior. Guilford, CT, Lyons Press.

Kirk, S. \& Kutchins, H. (1992). The selling of the DSM: The rhetoric of science in psychiatry. New Brunswick, NJ: Transaction Publishers.

Kirk, S. \& Kutchins, H. (1997). Making us crazy: DSM: the psychiatric bible and the creation of mental disorders. New York. The Free Press.

Kokkos, Alexis. (2010). Transformative Learning Through Aesthetic Experience: Towards a Comprehensive Method. Journal of Transformative Education 8(3), 155-177.

Kumagai, A. \& Wear, D. (2014). “Making strange:” a role for the humanities in medical education. Academic Medicine, 89(7), 973-977.

Laing, R. D. (1958/1965). The divided self. London: Pelican Books.

Litz, B., Stein, N., Delaney, E., Lebowitz, L., Nash, W. P., Silva, C., \& Maguen, S. (2009). Moral injury and moral repair in war veterans: A preliminary model and intervention strategy. Clinical Psychology Review, 29, 695-706.

Nash, W. P. \& Litz, B. (2013). Moral injury: a mechanism for war-related psychological trauma in military family members. Clinical Child and Family Psycholgy Review, 16, 356-375. 
Nazarov, A., Jetly, R., McNeely, H., Kiang, M., Lanius, R., McKinnon, MC. (2015). Role of morality in the experience of guilt and shame within the armed forces. Acta Psychiatrica Scandinavica (142), 4-19.

Pierce, S. (2013). Why taking risks comes with great rewards. November 11. Huffington Post. Retrieved from: http://www.huffingtonpost.com/stacia-pierce/why-taking-risks-comeswi_b_4235351.html

Schott, N. \& Spring, L. (2016). Contextualizing pro-ana/mia websites within neoliberal culture: Performance ethnography as a tool to disrupt the pathologizing of girls and women with troubled eating. Studies in Social Justice (Special Issue)

Schoenberger, C. (2016). Why Entrepreneurs bring benefits to corporate boards. May 1. Wall Street Journal. Retrieved from: http://www.wsj.com/articles/why-entrepreneurs-bringbenefits-to-corporate-boards- 1462155378

Shay, J. (1994). Achilles in Vietnam. New York: Scribner.

Shay, J. (2002). Odysseus in America: Combat trauma and the trials of homecoming. New York: Scribner.

Shay, J. (2009). The trials of homecoming: Odysseus returns from Iraq/ Afghanistan. Smith College Studies in Social Work, 79, 286-298.

Shay, J, (2014). Moral injury. Psychoanalytic Psychology, 31(2), 182-191.

Spring, L. (2016). Pathologizing military trauma: How service members, veterans, and those who care about them fall prey to institutional capture and the DSM. In Burstow. B. (Ed). Psychiatry Interrogated. Palgrave Macmillan.

Szasz, T. (1961). The myth of mental illness. New York: Paul B. Hoeber. 
Taylor, Edward (2008). Transformative learning theory. New directions for adult and continuing education, 119, pp. 5- 15.

Thompson, Megan. (2015). Moral injury in military operations: A review of the literature and key considerations for the Canadian Armed Forces. Defense Research and Development Canada, Scientific Report.

Warrell, M. (2013). Take a risk: the odds are better than you think. June 8. Forbes Magazine. Retrieved from: http://www.forbes.com/sites/margiewarrell/2013/06/18/take-a-risk-the-odds-are-betterthan-you-think/\#373520511d09

Whitaker, R. (2002). Mad in America. New York: Perseus Books.

Whitaker, R. (2010) Anatomy of an Epidemic. New York: Broadway Paperbacks 